\title{
The Effect of Shanghai-Hong Kong Stock Connect on Information Quality of Listed Company
}

\author{
Yan'e Kou \\ Yan'e Kou(1993-), Current Master Students, School of Economics and Management ,Xi’ dian university. China
}

\begin{abstract}
The Shanghai-Hong Kong stock connect policy is a milestone in the internationalization of China's capital markets.Based on the proportion of foreign investors under the Shanghai-Hong Kong stock connect policy, using the revised Jones model to measure information quality of listed company, the fixed effect model is constructed in order to explore the role of the shanghai-hong kong stock connect in the disclosure process of listed companies. The results show that Foreign investors under the shanghai-hong kong stock connect policy cannot directly improve the information quality of listed companies. Instead, it is to make a positive supervisory role in corporate governance by balancing the largest shareholder. This result Provides basis for policy-making and corporate governance.
\end{abstract}

Keywords: shanghai-hong kong stock connect policy; information quality of listed company; earnings management;corporate governance

\section{Introduction}

The Shanghai-Hong Kong stock connect has been officially launched on November 17, 2014, providing policy support for the capital linkage between the two cities. After Qualified Foreign Institutional Investors and Rmb Qualified Foreign Institutional Investors, The Shanghai-Hong Kong stock connect becomes another milestone in the internationalization of our capital markets. The one-way flow of capital flows into the Chinese stock market from a purely QFII institution has become a two-way flow of investment through the Shanghai-Hong Kong stock exchange. Singal from Shanghai port, The maximum amount of foreign funds entering the market through the Shanghai stock market will reach 13 billion yuan each day. Existing research shows that those capital have a certain influence on Shanghai stock market stability and co-movement between Shanghai port and HongKong port. The existing researches are always based on macroeconomic environment, while there are less research on the micro-impact of the stock connect policy on the governance of public companies.Foreign investors may oversee the quality of accounting information of listed companies in China and promote the reform of China's regulatory policies.So in the case of capital markets internationalization, the research on the influence of foreign capital on the information quality of listed companies is of great theory significance of foreign capital on the domestic stock market stability, also has policy, investment, analysis of the practical significance.

Combining theoretical analysis with empirical testing, the study finds that foreign investors under the Shanghai-Hong Kong stock connect have actively monitored corporate governance through check the number one shareholder. Compared to the present study, the contribution of this paper is to explore the influence of the Shanghai-Hong Kong stock exchange policy on the information quality of the listed companies in Shanghai.

\section{Literature Review and Hypothesis Derivation}

2.1Shanghai-Hong Kong stock connect policy research status

Shanghai-Hong Kong stock connect policy officially began on November 17, 2014 .It is of great significance in the internationalization of China's capital market. Because of it's great significance, at present, many scholars have begun the research of the Shanghai-Hong Kong stock connect, which can be divided into theoretical and empirical studies.

The research on the stock connect theory focuses on the advantages, risks and regulatory recommendations of the stock connect. In terms of advantages, the Shanghai-Hong Kong stock exchange has a significant effect on the internationalization of the RMB and the opening of the mainland capital account and Hong Kong port's perfect market mechanism provide the pricing closer to the reference and promote mainland financial market internationalization by Shanghai-Hong Kong stock connect policy(Ge Feng,2014 ${ }^{[1])}$. However, the Shanghai-Hong Kong stock exchange is prone to cross-border violations(Dai Jing, 2015 ${ }^{[2]}$ ), The rise and fall system has disrupted the normal operation of the stock market.Also ,there are many other risks in Shanghai-Hong Kong stock connect, such as arbitrage.

The empirical study is more on the stock market fluctuation. For example, Wang Xianzong $(2015)^{[3]}$, using the revised GRACH model, confirmed the link's impact on China's stock market volatility. The empirical results show that the "Shanghai tong" launched after the a-share market volatility is amplified, also confirmed the market impact of internal conduction has strong persistence, market gains is lifted. People like Pu Yang (2015) ${ }^{[4]}$, based on a comparison analysis of the AH premium index in different industries before and after the launch of the Shanghai-Hong Kong stock connect, found that investors' preference for investment was different. In particular, Hong Kong investors love a low valuation, a higher dividend yield, and a steady stream of shares. Most retail investors in mainland China are more focused on small and growing stocks. 


\section{International Journal of Science and Research (IJSR) \\ ISSN (Online): 2319-7064}

Index Copernicus Value (2015): 78.96 | Impact Factor (2015): 6.391

\subsection{The institutional investors on the quality of the accounting information of listed companies}

Institutional investor is the concept of relative to the general investor. It is a unique investment subject which is independent from the controlling shareholder and the small shareholders. With the professional analysis team, activity participating in incorporate governance through the resolution of shareholders, boards of directors resolution, Institutional investors have a positive monitoring effect on the external statements of enterprises (Chung,2002) ${ }^{[5]}$.Using data from India, Jayati Sarkar et al. 2008) ${ }^{[6]}$ finds that long-term oriented institutional investors can help reduce the earnings management, thus improving the quality of accounting information of enterprises. Michael Hadani et al. (2011) ${ }^{[7]}$, after examining the relationship between the number of shareholder proposals received by the company, institutional investors and earnings management, found that the number of shareholder proposals received by the company was positively related to its subsequent earnings management. But the largest institutional investors they monitored are negatively related to earnings management. Nadia Lakhal $(2015)^{[8]}$ uses information from French listed companies to point out that institutional investor holdings can effectively curb earnings management, thereby improving the quality of corporate accounting information. With the increase in the proportion of holdings, institutional investors are more willing to participate in corporate governance. The direct result of active supervision is to improve the quality of listed companies accounting information.

However, some scholars have questioned the positive supervision of institutional investors, and they believe that not all institutional investors can improve the quality of accounting information of listed companies. Grace C.-M. (2005) and Ling Lin (2012) $)^{[9]}$ have found that short-term institutional investor holdings are significantly positively correlated with earnings management due to the short-sighted investment phenomenon, which can not improve the quality of corporate accounting information.

In conclusion, there is no consensus on the impact of institutional investors on the quality of information disclosure. The main investors of Shanghai_HongKong stock connect are institutional investors. These foreign institutional investors have a wealth of investment experience and advanced investment vehicles (Black and Coffee, $1994^{[10]}$; Grinblatt and Keloharju,2000 ${ }^{[11]}$; Aggrwal et al.,2011 ${ }^{[12]}$, these advantages are conducive to promoting the active supervision of management and improving corporate governance by foreign investors. Therefore, this paper makes the following assumptions:

H1:The foreign investors under the policy of Shanghai _Hong Kong stock connect can effectively monitor the information quality of listed companies and play a positive role in corporate governance.

As a listed company's shareholders, Shanghai_Hong Kong stock connect investors will have an impact on the quality of listed corporate information disclosure. This is also one of the purposes of the implementation of Shanghai _Hong Kong stock connect. So, with the accumulation of time, the original intention of Shanghai_Hong Kong stock connect policy achieve or not, the existing research can not answer. The purpose of this paper is to answer this question, which is of theoretical and practical significance for the subsequent development of Shanghai_HongKong stock connect policy.

In order to further study the influence of Shanghai and Hong Kong on the information quality of listed companies, this paper presents the following assumptions 1.1 and 1.2 based on the above research status.

According to Hypothesis 1, the holdings of foeign investors under the policy of Shanghai_HongKong stock connect can improve the information quality of listed companies, thus weakening the asymmetry of information in the stock market.When foreign investors have a higher stake, they are more likely to "vote by hand" than "vote with their feet" ,because they have greater motivation and willingness to oversee the accounting information of listed companies. Therefore, this paper assumes the following assumptions according to Hypothesis 1.

H1.1 The higher shareholding, the more willingness to monitor the accounting information for foreign investors in Shanghai_HongKong stock connect policy.

The emptiness of big shareholders is the main reason that affects the quality of accounting information. Joboson et al. (2000) first proposed emptying behavior and classified them into three categories: operational emptying (including related party transactions and payment of executives high dividends and rewards), financial emptying. Research shows that the ability and motivation of large shareholders to empt the listed companies is significantly related to their shareholding ratio (Morck,1988).Based on the above considerations, this paper presents the following assumptions.

H1.2 The higher shareholder checks and balances of the foreign investors in Shanghai_HongKong stock connect, the more obvious the investors' active supervision of information disclosure.

\section{Variables and Model Selection}

This article selected the Shanghai_HongKong stock connect policy under the subject of the company for the study sample. Excluding the financial industry, the exact data, the remaining 298 companies, 298 companies are selected. All of the data is derived from Wind database.

\subsection{Explained variable}

This paper mainly explores the influence of foreign investors on the information quality of listed companies under the policy of Shanghai_HongKong stock connect policy, so the explanatory variables should represent the quality of information disclosure of listed companies. In the current 


\section{International Journal of Science and Research (IJSR) \\ ISSN (Online): 2319-7064}

Index Copernicus Value (2015): 78.96 | Impact Factor (2015): 6.391

study, mainly use earnings management(Incheol Kim et al.,2016), accounting level of conservatism(Dong Jianping,2016) to measure the quality of Information Disclosure of Listed Companies. Taking into account the availability of data and the comprehensiveness of the measurement of indicators, this paper chooses the earnings management and real activity earnings management under the manipulative accrual profit model to measure the quality of information disclosure of listed companies.

\section{(1) Earnings Management (EM)}

Currently, the more common model of calculating earnings management is the Jones model. The model argues that non-manipulation should be influenced by two factors: changes in operating income and fixed asset levels.Later, Dechow, Sloan and Sweeney (1995) and others on the basis of the perfect, they believe that managers can use sales to manipulate accruals, it should be excluded from the impact of accounts receivable, which is modified Jones model.This paper selects the modified Jones model to calculate earnings management.

The modified Jones model is shown below: accounts receivable at period $\mathrm{t}$ and $\mathrm{t}-1 . \alpha_{1}, \partial_{2}, \partial_{3}$ is the company characteristic parameter. According to the above model, the company's earnings management can be calculated.

\section{(2)Real Activity Earnings Management}

In order to fully reflect the situation of enterprise earnings management, learn from the practice of Roy Chowdhury (2006) ,using three models to reflect the real earnings management activities of enterprises. The Roy Chowdhury (2006) argues that the company's cash flow and production costs can be reasonably expected through current sales and sales variances, and that the normal value of the discretionary costs can be expected through discretionary fees and previous sales revenue .According to the above ideas, we make the following regression model to calculate the residual, the residual is the corresponding real activity surplus management.

\section{a. Handing business cash flow $(\mathrm{HBCF})$}

$N D A_{t} / A_{t-1}=\partial_{1}\left(1 / A_{t-1}\right)+\partial_{2}\left[\Delta R E V_{t}-\Delta R E C_{t} / A_{t-1}\right]+\partial_{3} \underset{A_{i, t-1} P E_{t}^{i, y}}{H A} \alpha_{0, i}+\alpha_{1, i}\left(\frac{1}{A_{i, t-1}}\right)+\alpha_{2, i}\left(\frac{R E V_{i, t}}{A_{i, t-1}}\right)+\alpha_{3, i}\left(\frac{\Delta R E V_{i, t}}{A_{i, t-1}}\right)+\varepsilon_{i, t}$

In the formula, $N D A_{t}$ indicates the non-manipulative accrual profit of the $\mathrm{t}$-th period after the end of period $\mathrm{t}-1$, and the earnings management EM in this paper.

$A_{t-1}$ represents the total assets of t-1. ${ }^{\triangle R E V_{t}}$ represents the difference between income from period $t$ and income of period t-1. $P P E_{t}$ represents the total value of fixed assets in period t. $\triangle R E C_{t}$ represents the difference between

$H B C F_{i, t}$ represent operating cash flow of company i.

$A_{i, t-1}$ represents the total assets of Company iin the period t-1. $R E V_{i, t}$ represents income for company $\mathrm{i}$ in period t. $\triangle R E V_{i, t}$ indicates the difference between the income of period $\mathrm{t}$ and the income of period $\mathrm{t}-1$ for company i.

\section{b. Handing the production cost(HPC)}

$$
\frac{H P C_{i, t}}{A_{i, t-1}}=\alpha_{0, i}+\alpha_{1, i}\left(\frac{1}{A_{i, t-1}}\right)+\alpha_{2, i}\left(\frac{R E V_{i, t}}{A_{i, t-1}}\right)+\alpha_{3, i}\left(\frac{\Delta R E V_{i, t}}{A_{i, t-1}}\right)+\alpha_{4, i}\left(\frac{\Delta R E V_{i, t-1}}{A_{i, t-1}}\right)+\varepsilon_{i, t}
$$

Where HPC represents the cost of production, which is equal to the current sales cost and the current inventory changes and the sum.

\section{Handing fee (HF)}

$$
\frac{H F_{i, t}}{A_{i, t-1}}=\alpha_{0, i}+\alpha_{1, i}\left(\frac{1}{A_{i, t-1}}\right)+\alpha_{2, i}\left(\frac{R E V_{i, t-1}}{A_{i, t-1}}\right)+\varepsilon_{i, t}
$$

HF represents a discretionary fee equal to the sum of the cost of sales and management.

\section{d. The real total earnings management (REM)}

$$
R E M_{i, t}=H P C_{i, t}-H B C F_{i, t}-H F_{i, t}
$$

Taking into account the actual situation,combined with McNichols' (2000) opinion,In this paper, the sample data are analyzed quarter by quarter.

The selection of indicators in this paper is shown in the table below. 
International Journal of Science and Research (IJSR)

ISSN (Online): 2319-7064

Index Copernicus Value (2015): 78.96 | Impact Factor (2015): 6.391

Table 1: Variable selection and description

\begin{tabular}{|c|c|c|c|}
\hline \\
\hline classification & index & For short & description \\
\hline \multirow[t]{5}{*}{ Explained variable } & Earnings Management & EM & Reflect the quality of information disclosure of listed companies \\
\hline & \multirow{4}{*}{$\begin{array}{l}\text { Real Activity Earnings } \\
\text { Management }\end{array}$} & $\mathrm{HBCF}$ & Reflecting the degree of control of cash flow by listed companies \\
\hline & & HPC & Reflecting the control of the production costs of listed companies \\
\hline & & $\mathrm{HF}$ & Reflecting the control of the cost of listed companies \\
\hline & & REM & Reflecting the total amount of earnings management of listed companies \\
\hline \multirow[t]{2}{*}{ Explanatory variables } & $\begin{array}{l}\text { The sharehonding ratio } \\
\text { of Shanghai_HongKong } \\
\text { stock connect investors }\end{array}$ & $\mathrm{SH}$ & The shareholding ratio of Shanghai_HongKong stock connect investors \\
\hline & $\begin{array}{c}\text { The balance of the } \\
\text { largest shareholder of } \\
\text { the ability }\end{array}$ & SHRP & $\begin{array}{l}\text { Shanghai_HongKong stock connect investors on the listed company's } \\
\text { largest shareholder checks and balances. }\end{array}$ \\
\hline \multirow[t]{4}{*}{ Control variable } & Capitalization ratio & $\mathrm{CR}$ & $\begin{array}{l}\text { Equal to the total value of the stock market divided by GDP, reflecting } \\
\text { the degree of development of the market economy }\end{array}$ \\
\hline & The size of company & SIZE & $\begin{array}{l}\text { The total assets of the logarithm, reflecting the financial strength of listed } \\
\text { companies }\end{array}$ \\
\hline & Return on assets & ROA & Reflecting the business and profitability \\
\hline & Assets and liabilities & LEV & Reflect the corporate debt structure \\
\hline
\end{tabular}

\subsection{Model selection}

The following regression model is chosen to validate the hypothesis.

$$
E M_{i, t}=\alpha_{0}+\alpha_{1} S H_{i, t}+\alpha_{2} S H R P_{i, t}+\alpha_{3} C R_{i, t}+\alpha_{4} S I Z E_{i, t}+\alpha_{5} R O A_{i, t}+\alpha_{6} L E V_{i, t}
$$

\section{Empirical Analysis}

\subsection{Descriptive Statistics}

Based on the above samples and data, the descriptive statistics of variables are shown in table 2 .

Table 2: The descriptive statistics of variables

\begin{tabular}{|c|c|c|c|c|c|}
\hline & $N$ & minimum & maximum & Mean value & $\begin{array}{c}\text { standard } \\
\text { deviation }\end{array}$ \\
\hline SH & 2384 & 0 & 0.1611 & 0.003238955 & 1.1966471 \\
\hline SHRP & 2384 & 0 & 0.7804323 & 0.1162575 & 0.0501635 \\
\hline EM & 2384 & 0.0000975 & 3.2649700 & 0.1978718 & 0.2564991 \\
\hline HBCF & 2384 & 0.0000985 & 1.3179660 & 0.6768921 & 0.8413650 \\
\hline HPC & 2384 & 0 & 0.5790550 & 0.4976536 & 0.0622371 \\
\hline HF & 2384 & 0.0000575 & 0.4034413 & 0.0303537 & 0.0440220 \\
\hline REM & 2384 & 0.0000474 & 1.5548090 & 0.0861481 & 0.1116932 \\
\hline CR & 2384 & 0 & 0.0706370 & 0.0004242 & 0.0020750 \\
\hline SIZE & 2384 & 12.296380 & 28.514170 & 23.0851369 & 2.3980802 \\
\hline ROA & 2384 & -9.5647000 & 37.392300 & 4.23465789 & 4.1774919 \\
\hline LEV & 2384 & 3.2385000 & 89.669100 & 49.4937612 & 18.8262449 \\
\hline
\end{tabular}

As is shown in table2,the maximum proportion of the shareholding ratio of Shanghai_HongKong stock connect investors is $16.11 \%$, the average is only about $0.3 \%$.Indicating that the shareholding of the Shanghai_HongKong stock connect investors the shareholding is still relatively low. This phenomenon may affect the extent of the description of the model, the smaller shareholding ratio may be listed on the quality of information disclosure of the positive role of monitoring is not so obvious. The maximum amount of checks and balances of large shareholders is 0.78 , means the degree of checks and balances is large. From the perspective of earnings management, almost all companies have earnings management, in addition to HPC (manipulative production costs), and this phenomenon may be related to the company's industry.

\subsection{Correlation analysis}

The correlation analysis results are shown in Table 3 .

Table 3: Correlation analysis

\begin{tabular}{|c|c|c|c|c|c|c|c|c|c|c|c|}
\hline & SH & SHRP & EM & HBCF & HPC & HF & HEM & CR & SIZE & ROA & LEV \\
\hline SH & & & & & & & & & & & \\
\hline SHRP & $0.789^{* *}$ & & & & & & & & & & \\
\hline EM & -0.16 & -0.002 & & & & & & & & & \\
\hline HBCF & -0.27 & -0.15 & $0.265^{* *}$ & & & & & & & & \\
\hline HPC & $0.141^{* *}$ & $0.205^{* *}$ & $0.260^{* *}$ & $0.364^{* *}$ & & & & & & & \\
\hline HF & $0.118^{* *}$ & $0.225^{* *}$ & $0.255^{* *}$ & $0.225^{* *}$ & $0.742^{* *}$ & & & & & & \\
\hline REM & $0.094^{* *}$ & $0.148^{* *}$ & $0.123^{* *}$ & $0.528^{* *}$ & $0.569^{* *}$ & $0.723^{* *}$ & & & & & \\
\hline CR & $0.051^{* *}$ & 0.33 & 0.015 & -0.035 & 0.012 & -0.021 & -0.012 & & & & \\
\hline SIZE & $0.065^{* *}$ & $0.045^{*}$ & -0.023 & $-0.0136^{* *}$ & $-0.167^{* *}$ & $-0.109^{* *}$ & $-0.091^{* *}$ & $0.192^{* *}$ & & & \\
\hline
\end{tabular}

Volume 6 Issue 7, July 2017 www.ijsr.net 
International Journal of Science and Research (IJSR)

ISSN (Online): 2319-7064

Index Copernicus Value (2015): 78.96 | Impact Factor (2015): 6.391

\begin{tabular}{|c|c|c|c|c|c|c|c|c|c|c|c|}
\hline ROA & $0.215^{* *}$ & $0.175^{* *}$ & $0.213^{* *}$ & $0.176^{* *}$ & $0.378^{* *}$ & $0.338^{* *}$ & $0.298^{* *}$ & $0.043^{* *}$ & 0.013 & & \\
\hline LEV & $-0.137^{* *}$ & $-0.085^{* *}$ & 0.04 & $0.047^{*}$ & $-0.156^{* *}$ & $-0.217^{* *}$ & $-0.154^{* *}$ & 0.007 & $0.256^{* *}$ & $-0.346^{* *}$ & \\
\hline
\end{tabular}

Note: $* * *$ indicates that at $1 \%$ confidence level, $* *$ indicates a significant level of $3 \%$ confidence level and $*$ indicates significant at $5 \%$ confidence level. The following table is the same.

As is shown in table 3,the shareholding of Shanghai_HongKong stock connect investors and accrual items earnings management, manipulative operating cash flow are negatively correlated, to some extent supported the H1.1 .However, it is significant correlation with manipulative production costs, handling costs, and real activity earnings management. This phenomenon means the fact that, the higher the proportion of Shanghai_HongKong stock connect investors' shareholding, the higher the degree of control of production costs and expenses, and the greater degree of information asymmetry. The influence of foreign institutional investors on the balance of the largest shareholder is similar to the above. The following is a more in-depth verification of their relationship by selecting the appropriate regression model.

\subsection{Regression analysis}

By analyzing the short panel data involved in the article with the stata software, the sample data is balanced panel data and passed the stability check. It is proved that the fixed effect model is superior to the random effect model and the ordinary least squares regression analysis model, and the model does not include the time effect. The specific regression results are shown in Table 4 below.

Table 4: Regression analysis results

\begin{tabular}{|c|c|c|c|c|c|}
\hline & $(1)$ & $(2)$ & $(3)$ & $(4)$ & $(5)$ \\
\hline & EM & HBCF & HPC & HF & REM \\
\hline SH & 0.0157203 & 0.0000975 & 0.0007306 & 0.0002372 & 0.0042126 \\
\hline SHRP & -0.5848044 & 0.0298416 & -0.0401714 & -0.0366601 & -0.2359184 \\
\hline CR & 1.450799 & -0.2428629 & 0.174789 & 0.610451 & 0.072674 \\
\hline SIZE & -0.1096245 & $-0.0135643 * * *$ & -0.0078625 & -0.0085125 & -0.0077821 \\
\hline ROA & 0.0249332 & 0.0068627 & $0.0065859 * * *$ & $0.0044277 * * *$ & $0.910594 * * *$ \\
\hline LEV & 0.0025054 & 0.0000816 & $0.0007977 * * *$ & $0.00045^{* * *}$ & $0.0010435^{* * *}$ \\
\hline -cons & 2.497106 & 0.3474489 & 0.1641261 & $0.1861704 *$ & 0.1686665 \\
\hline & & & & & \\
\hline R square & 0.1716 & 0.1268 & 0.2048 & 0.2910 & 0.2205 \\
\hline $\mathrm{F}(6,2080)$ & 71.49 & 50.33 & 89.27 & 142.3 & 98.05 \\
\hline Prob>F & 0.0000 & 0.0000 & 0.0000 & 0.0000 & 0.0000 \\
\hline
\end{tabular}

Table 4 regression model was statistically significant. There are positive correlations between the shareholding of Shanghai_HongKong stock connect investors and accrual projects, the operating cash flow, the controlled production cost, the manipulative discretion fee and the real event earnings management (The coefficients are 0.0157203, $0.0000975,0.0007306,0.0002372$ and 0.0042126).That means the Shanghai_HongKong stock connect investors do not play a role in monitoring the quality of information on listed companies, assumption H1.1 is overturned. Under the Shanghai_HongKong stock connect policy, Offshore Institutional Investor 's Shareholding Ability to Large Shareholders (SHRP) has a certain inhibitory effect on earnings management, manipulative production costs, manipulative discretionary fees and real activity earnings management (the coefficients are $-0.5848044,-0.0401714$, -0.0366601, -0.2359184).Hypothesis H1.2 has been supported .

\section{Conclusion}

Based on the information disclosure of listed companies, this paper study the effect of Shanghai_HongKong stock connect policy on the corporate governance. The results shows that, Shanghai_HongKong stock connect investors can not be affected the quality of information disclosure by shareholding behavior,but have a certain checks and balances on the company's largest shareholder. That is to say, they can balance the shareholders of listed companies to play a positive role in monitoring. Because of it's daily trading volume' maximum of 13 billion yuan daily trading volume and short opening time,the positive supervision effect of Shanghai_HongKong stock connect investors on the governance of listed companies is not obvious. Shanghai_HongKong stock connect investors are more in the capital market to play "speculators" rather than "investors" role.

The following test is proposed for the above conclusions. First, for the regulatory authorities, domestic and foreign institutional investors in the capital market information environment only a certain role in the supervision. Regulatory authorities should strengthen the corresponding policy oversight in order to male the information disclosure of listed companies more perfect and the capital market more orderly. Second, we should strengthen the implementation of the Shanghai-Hong Kong stock connect. Third, investors should invest rationally and not blindly follow institutional investors.

\section{Volume 6 Issue 7, July 2017 www.ijsr.net}




\section{International Journal of Science and Research (IJSR) \\ ISSN (Online): 2319-7064}

Index Copernicus Value (2015): 78.96 | Impact Factor (2015): 6.391

The innovation point of this paper is to study the effect of the stock connect policy on the information quality of the listed company, and make up the gap in that direction.The deficiency of this paper is that there are fewer samples (only 2384), and the data volume is too small, which may affect the research results.

\section{References}

[1] Ge Feng."Shanghai_Hong Kong stock connect program" accelerate the mainland stock market "mature"[J].China Economic Weekly,2014,(15):4.(in Chinese).

[2] Dai Jin. The market impact and financial risks brought by Shanghai_Hong Kong stock connect program[J].Chinese market.2015, ( 39 ) :12-13.(in Chinese).

[3] Wang Xianzong. The Impact of Shanghai_Hong Kong Pass on the Fluctuation of Shanghai A - share Index[J].Journal of the Post graduate of Zhongnan University of Economics and Law.2015, (05 ):60-67.(in Chinese)

[4] $\mathrm{Pu}$ Yang et.al..The impact of the arrival of Shanghai-Hong Kong stock connect on the AH share premium index[J].times finiance.2015(610):112.(in Chinese).

[5] Chung,R.M.Firth and FJ,B.Kim. Institutional ownerships capital structure and firm performance[J].Journal of Corporate Finance,2002(8):29-48

[6] Jayati Sarkar,Subrata Sarkar,Kaustav Sen et al.Board of Directors and Opportunistic Earnings Management: Evidence from India[J].Journal of accounting, auditing \&amp; finance,2008,23(4):517-551.

[7] Michael Hadani,Maria Goranova,Raihan Khan et al.Institutional investors, shareholder activism, and earnings

[8] Nadia Lakhal.Corporate Disclosure, Ownership Structure And Earnings Management: The Case Of French-Listed Firms[J].The journal of applied business research,2015,31(4):1493-1504.

[9] Ling Lin,Pavinee Manowan.Institutional Ownership Composition and Earnings Management[J].Review of Pacific Basin financial markets and policies,2012,15(4):1250022.1-1250022.22.

[10] Black,B.S.,Coffoe,J.C.,1994.Hail Britannia?Institutional investor behavior under limited regulation.Mich.Law Rev.92(7),1997-2087.

[11] Grinblatt,M.,Keloharju,M.,2000.The investment behavior and Performance of various investor types:a study of Finland's unique data set[J].Financ.Econ.55(1), 43-67.

[12] Aggarwal,R.,Erel,I.,Ferreira,M.,Matos,P.,2011.Does governance travel around the world?Evidence from institutional investors[J].Financ.Econ.100(1),154-181.

Volume 6 Issue 7, July 2017 www.ijsr.net 